Original manuscript of Reed, $K$ and Ryan, $P$ (2019) Lessons from the past and the future of food, World Archaeology, 51:1, 1-16, an article published by Taylor \& Francis in [WORLD ARCHAEOLOGY] on 16 May 2019 available at https://doi.org/10.1080/00438243.2019.1610492

\title{
ARTICLE
}

\section{Lessons from the past and the future of food}

Kelly Reed a and Philippa Ryan ${ }^{\mathrm{b}}$

a Oxford Martin School, University of Oxford, Oxford, UK; ' ${ }^{\mathrm{b}}$ conomic Botany, Royal Botanic Gardens, Kew, Richmond, UK

\begin{abstract}
Perspectives from the recent and ancient past are largely underutilized in mod- ern sustainability or food systems studies. However, information about regional crop histories and land use systems through time can add essential value and context to debates concerning future agricultural strategies and food security. In particular, archaeological and anthropological research can provide long-term perspectives on adaptive solutions and agricultural resilience that could support strategies for sustainable agriculture, especially in developing countries. This paper explores this debate within a food systems framework and highlights the need for researchers to work across disciplines and sectors to share knowledge, exchange ideas and create solutions in order to meet the challenges of feeding the world in a healthy, equitable, sustainable and resilient way.
\end{abstract}

\section{KEYWORDS}

Archaeology; anthropology; food security; food systems; sustainability; resilience; underutilised crops; land use

\section{Introduction}

Today world agriculture is facing major challenges, such as how to feed a growing world population, how to reduce rural poverty, and how to manage ecosystem goods and services in light of global environmental change (GEC) (e.g. Godfray et al. 2010; Godfray and Garnett 2014; Springmann et al. 2018). Over the last 200 years agriculture has generally kept pace with a population that has increased six-fold, but many of the methods to increase outputs, such as land area expansion and the introduction of Green Revolution crops, that require high levels of fertilizers and pesticides, are unsustainable and still result in more than a billion people being undernourished. Ultimately, the state of the planet and human well-being are affected by how we manage our food system; hence why seeking a productive, resilient, sustainable and socially fair food system is now a major global priority (e.g. Campbell et al. 2014; Tilman et al. 2011).

Traditionally, components of modern production and consumption systems have been assessed or analysed in individual studies to improve the efficiency of each element, based on the assumption that this will also improve the efficiency of the whole system. However, over the last few decades, it has become clear that a more holistic framework is needed to address these complex issues. As a result, a food systems approach has been widely adopted to identify, analyse and assess the impact and feedback of the systems different actors, activities and outcomes to help identify intervention points for enhancing food security (Ericksen 2008; Ingram 2011). Yet, to understand the full range of drivers some studies would benefit from longitudinal information covering decades or centuries.

Concern for human impact on the environment and agricultural sustainability is also evident in research of past societies (e.g. Ellis et al. 2013; Kerner, Dann, and Bangsgaad 2015; Kirch 2005; Marston 2017; Redman 1999; Rosen 2007), yet this body of work is largely underutilized in modern sustainability or development orientated studies. The study of subsistence systems from the ancient past through to the last century can provide important insights into future agricultural resilience by exploring the role, value, and cultivation of local food crops in parts of the world where dramatic long-term changes have been seen. Establishing which long-term food crops are falling from favour contributes to current debates 
about the role of neglected crops and their importance to future food security (Ryan and Homewood 2016). Archaeological and anthropological enquiry can also inform on the sustainability of present-day and future agricultural land use strategies (Stump and Richer 2017).

Perspectives from the past also have the ability to contribute towards a number of the United Nations Sustainable Development Goals (SDGs), such as zero hunger (SDG 2) ensuring sustainable and resilient food production systems, and Life below Water and on Land (SDG 14, 15) to sustainably manage and protect marine and coastal ecosystems and conserve and restore degraded land and soil to achieve a landdegradation-neutral world. Consequently, the increasing interdisciplinary nature of food system research opens up a unique opportunity for archaeology and anthropology to contribute to the current debate on how to transform our food system. Moreover, the food system framework has the potential to be a useful tool to explore past societies and allow archaeology to investigate more fully issues around food security and agricultural development over time and under different challenges. This paper considers the case for integrating archaeology and anthropology into current food systems debates and how the adoption of a food system framework may contribute to archaeological and anthropological research. This discussion follows on from a recent conference organized by the authors exploring the contribution of archaeological and anthropological perspectives to future food security issues http://www.futureoffood.ox.ac.uk/events/ lessons-past-archaeology-anthropology-and-future-food-oxford. This paper does not aim to address all aspects of agricultural sustainability, but to highlight key topics and avenues of research.

\section{The value of a "food systems" approach}

The food system, in the sense we use it here, is a complex web of activities involving the production, processing, transporting, and consumption of food (see Ericksen 2008; Ingram 2011 for further discussions). It includes the governance and economics of food production, its sustainability, the degree to which we waste food, and how food production affects the natural environment (Figure 1). The food system, therefore, includes all of the processes and infrastructure involved in feeding a population and can contain an array of smaller systems such as agroecological, economic, and social systems. Within those are further sub-systems, such as water, energy, financing, marketing, and policy. Social aspects of the food system include health, food safety, nutrition, culinary, and dietary cultural factors. The inter- connected and dynamic nature of the food system allows outcomes to be achieved via many possible pathways, and to be influenced by many factors, but also means that unanticipated outcomes and unintended consequences may occur (Reed et al. 2017). Thus, looking at food systems we put these activities in their socioeconomic, political, and environmental context, allowing us to think about the different actors, drivers, outcomes and trade-off's that are influenced at multiple scales from the house- hold to the global level (Ericksen 2008; Ingram 2011). As food systems are inherently multi-scale and multi-level, adaptation options must recognize both cross-scale and cross-level interactions.

Adopting the food systems framework has proven valuable in framing GEC/food security research questions from a more holistic perspective at multiple scales (e.g., FAO 2017b; Ingram, Ericksen, and Liverman 2010; Termeer et al. 2018). Ingram (2011) also highlights the value of this concept for analysing vulnerability and adaptation options, as well as scenarios for examining the consequences of interventions on food security outcomes. In archaeology, the implications for applying this method are beneficial in that it provides a common framework for thinking about the past from the Palaeolithic through to the present day. This allows a temporal comparison of food system processes, as food systems are constantly changing through time. The complexity of the food system and the fragmentary archaeological record also mean that no one source of evidence should be assessed in isolation. The framework therefore helps fit together the wide range of archaeological and anthropological information for a more holistic picture, e.g., pottery (e.g., serving food), buildings (e.g. pottery, storage), stone and metal objects (e.g. agricultural and food preparation equipment, coins), and organic matter (e.g. animal bones and plant remains), as well as sources of a literary, iconographic or verbal nature (Figure 2). 


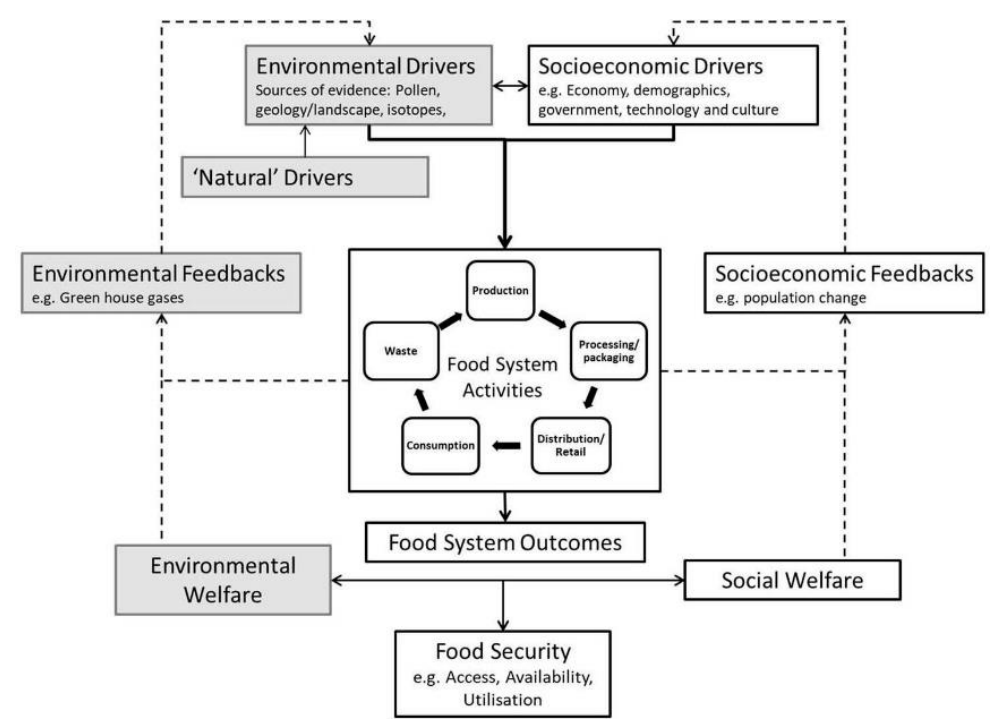

Figure 1. The food system and its drivers. Adapted from Ericksen 2008.
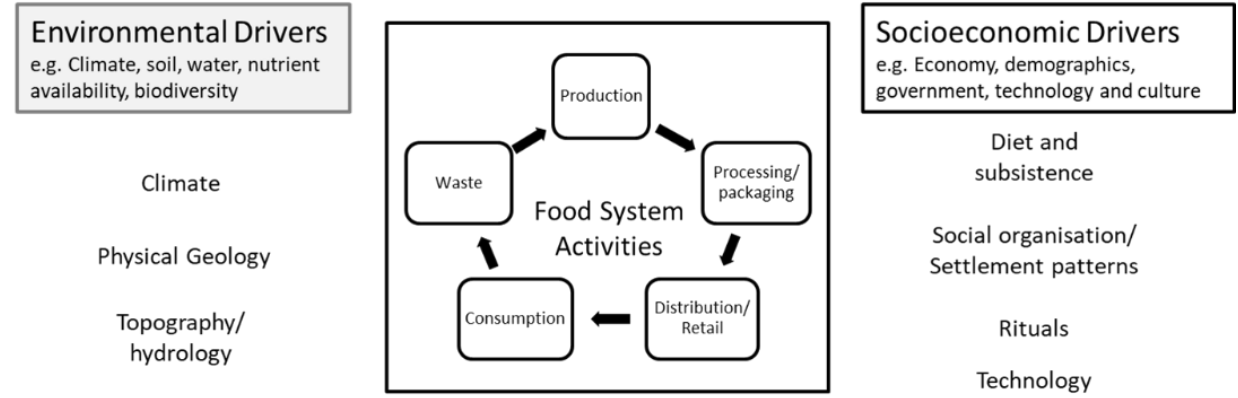

Figure 2. Interpreting past food systems

\section{Approaching food security in the past}

Food security is defined 'when all people, at all times, have physical and economic access to sufficient, safe and nutritious food to meet their dietary needs and food preferences for an active and healthy life' (FAO 1996). Several factors have been identified as critical to food security:

- Availability: having sufficient quantities, variety, and quality of food available on a consistent basis. Three elements, production, distribution, and exchange contribute to food availability.

- Accessibility: having the resources to obtain the type, quality and quantity of food required. Three elements describe food accessibility: affordability, allocation, and preference.

- Use and Utilization is the capacity of an individual or household to consume and benefit from the food. The three elements of food utilization are nutritional value, social value, and food safety.

- Stability is also crucial for all three dimensions over time. War is generally acknowledged to have major disruption on food supplies leading to significant malnutrition and famine.

Although the nature of food production and consumption was transformed in the late 20th century, challenges that face us today are not new and many past societies have struggled with similar issues such as population growth, resource competition and scarcity, environmental change, and the need for agricultural intensification and increased production. Many sources of evidence are available to explore past food systems in archaeology and anthropology, such as through iconography, physical remains, chemical analyses, written and verbal histories, etc., and many have already provided chronologically longitudinal high-resolution studies. This section presents some of the research that 
has explored issues around agricultural sustainability, and their importance and relevance to current debates on managing future food systems.

\section{Environmental change and resilience}

Climate variability is one of the most significant factors influencing year to year crop production, even in high-yield and high-technology agricultural areas. In recent years, more and more attention has been paid to the risks associated with climate change, which will increase uncertainty with respect to food production (Rosenzweig et al. 2001). However, archaeology, which has a long history of studying multi-decadal-to-multi-century human-environment interactions, plays a limited role in contemporary debates on tackling climate challenges (e.g. Cooper and Sheets 2012; Costanza, Graumlich, and Stefen 2007; DeMenocal 2001; Jackson, Dugmore, and Riede 2017; Rockman 2011). Social-ecological resilience research within some global development studies includes exploring the range of risks, including to food security, of increasing human impact on ecology during the Anthropocene (Graid 2018). In this instance, the timing of the Anthropocene is assessed as beginning during the 1950s, because of escalating social, economic, and ecological changes since that time - although the long-term impact of humans on the environment is still seen as important (Graid 2016, 2018). Environmental archaeology is contributing to debates about the timing of the Anthropocene, for example due to the ecological impact of intensive farming systems in the past, and the contribution of certain types of farming to methane levels over millennia (Fuller et al. 2011; Laparidou and Rosen 2015; Ruddiman et al. 2016). The value of multi- disciplinary knowledge, including from archaeology and history, within development-related resilience theory modelling, and its applications is highlighted by van der Leeuw (2008). Vulnerability, adaptability, and resilience can also be plotted alongside socio-economic systems to provide an encompassing perspective on the fluctuations of societies in relation to environ- mental and social processes (Marston 2015; Redman 2005). Figure 3 is a schematic framework which shows this interrelationship between the earth and human system and how they are both drivers of change with both positive and negative feedbacks (Bernstein et al. 2007, 26). This framework has been used as an example of conceptualizing climate change archaeology that interconnects people and communities within the landscape they inhabit (Van de Noort 2011a).

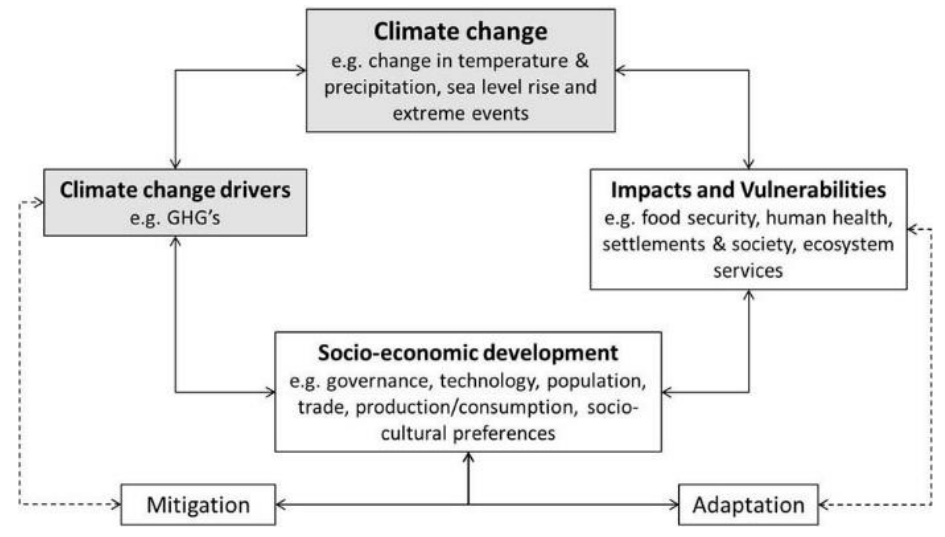

Figure 3. The interrelationship of climate change and cultural change (adapted from Bernstein et al. 2007, 26).

Several abrupt climatic events occurred during the Holocene, such as the $8.2 \mathrm{ka}$ BP event, and archaeological studies are showing that in certain cases farmers were able to successfully cope with rapid climate change in a range of environments through risk management strategies, such as buffering or diversification (Bogaard et al. 2017; Flohr et al. 2016; Ryan and Rosen 2016). In addition, when 'collapse' is observed, this is rarely due to simply climatic deterioration but rather a range of complex factors (Flohr et al. 2016; Scarborough 2010; Turner and Sabloff 2012). An 
interesting example of 'success' is the complex mix of adaptations from communities to volcanic disasters. Volcanoes are hazardous due to their unpredictability and their ability to pose as a seemingly innocuous mountain, but the scale of impact can be quite variable. Although mass extinctions do occur, there are more examples of human adaptation and resilience and the positive effects that volcanic events can have on the environment and on cultural processes (Grattan and Torrence 2007). In particular, the addition of mineral-rich tephras can increase soil fertility and agricultural productivity.

Impacts of climate change, trade and the economy are seen to be interconnected in a number of past societies. In particular, cases of past societal collapse can help to explain how a socioeconomic organization can limit adaptability to environmental change. For example, the occupation of Greenland between AD 950 and 15th century by the Vikings rapidly transformed the local landscape to accommodate the recently settled farming communities; however, during the 13th-14th century the climate became colder (Medieval Cold Period) and traditional agricultural techniques began to fail (Dugmore et al. 2012; Kintisch 2016; McGovern et al. 1988). In response, the Norse turned from their struggling farms to the sea for food (Arneborg, Lynnerup, and Heinemeier 2012). But as food sources dwindled the climate also disrupted their trade, which coincided with the market value of ivory collapsing in Europe around 1400 (Star et al. 2018). This all culminated in the Norse finally abandoning their settlements in Greenland in the 15th century (Dugmore et al. 2012). In contrast, the local Inuit groups survived having already been exposed for a long time to low annual temperatures typical of the Arctic, lived on a traditional diet rich in protein mostly from marine mammals with high levels of omega-3 fatty acids and were not dependant on the trade market (Fumagalli et al. 2015).

Rising sea levels are also a major concern and archaeology can provide useful information on how communities have dealt with landscape change (i.e., loss of land), economic damage and social upheaval (e.g., Nunn and Kumar 2018; Van de Noort 2011b). Around the North Sea today we see hundreds of years of adaptation and change in the landscape from the building of embankments and dikes to land reclamation and the extension of arable land (Rippon 2000; Van de Noort 2011a). In the late Middle Ages, the coastal wetlands along the southern North Sea area were increasingly hit by a series of catastrophic storm surges. Where flood protection (e.g., sea walls) were in place, historians note that their maintenance was regularly impacted by the economy, so when crop or wool prices fell stakeholders in coastal societies would opt to reduce the level of sea wall protection (Soens 2013). Other societal impacts are seen in the tropical pacific islands where significant changes in settlement patterns around the 13th-15th Century AD are believed to have occurred when food crises and warfare arose as a result of the sea level falling (Nunn and Kumar 2018).

\section{Agricultural diversity}

Of Earth's estimated 400,000 plant species, 300,000 are edible, yet humans cultivate only around 150 species globally, and half of our plant-sourced protein and calories come from just three: maize, rice, and wheat (Shelef, Weisberg, and Provenza 2017). The UN Food and Agriculture Organization (FAO 2004) also estimates that $75 \%$ of the food crops grown 100 years ago have disappeared from farmers' fields and are functionally extinct. As a result, greater uniformity of crops is grown over larger areas, making agriculture more vulnerable to major threats, such as pests and diseases, and, now, climate change (Fisher et al. 2012; Pingali 2012; Strange and Scott 2005). Even in our recent history episodes such as the Irish Potato Famine show the vulnerabilities within our food system, and the risk of relying on monoculture. Increasing crop diversity and reintroducing underutilized crops is therefore believed to be one element to addressing the effects of long-term climate change, whilst also tackling the problems of dietary imbalances that face many parts of the world today (FAO 2017a; Massawe, Mayes, and Cheng 2016). Information about recent and ancient crop histories and agrobiodiversity can add essential value and context to debates concerning future crop introductions at the local level and highlight regions where crops were once grown. One previously almost forgotten crop is quinoa (Chenopodium quinoa), which two 
decades ago was classed as a lost crop of the Incas, but soon became a globally consumed commercial crop (Skarbø 2015). However, in this case, intensive cultivation of quinoa has resulted in complex environmental and economic problems in Bolivia (Jacobsen 2011). Thus, the introduction of improved seeds or underutilized crops would benefit from being integrated within the context of the local farming systems in light of their environmental, economic, and social impacts. Although many recognize that diversity can improve the resilience of agricultural systems to environmental change, the adoption of increased diversification has been slow for a number of reasons (Lin 2011). First, economic policy incentives for the production of monoculture crops under intensive management have overshadowed incentives to implement diversification, especially as monoculture is believed to be more productive than multispecies systems (e.g., Bowman and Zilberman 2013). Second, many have focused on the development of biotech solutions to produce insect and drought-resistant crops, pushing agriculture toward more expensive and intensive forms of management (e.g., Azadi et al. 2016). Third, farmers are conscious of the global market and consumer demand will be a key influencing factor in the uptake of any new species (e.g., Bowman and Zilberman 2013). Fourth, is the unknown cultural and social implications and impact of adopting new species, especially in small-holder communities.

Traditional forms of farming across many areas of the globe are rapidly changing or disappearing due to major social, political, economic, and environmental changes (e.g., Ryan 2017). Yet, indigenous groups and subsistence farmers offer alternative knowledge and perspectives based on their own locally developed practices of resource use. These include multiple species and succession management, resource rotation, landscape patchiness management and many other ways of responding to ecological risks (e.g., Berkes, Colding, and Folke 2000). Diversification to manage risk can include using a wide range of crops and livestock, wild foods, and using a variety of types of fields (e.g., Halstead and O'Shea 1989). Crop diversification can also have economic benefits for some farmers by offsetting fluctuations in the market price for major crops. Generally, native plants require lower inputs of water, nutrients, pest control and energy and so are an important natural resource. Many also advocate the integration of crops and livestock to produce a healthy, sustainable farm system as it builds soil fertility without the need for chemical fertilisers, and increases diversity, which is beneficial for both people and wildlife (e.g., Lemaire et al. 2014). However, with the influx of 'cash' crops many indigenous crops are being marginalized, which not only impact ecosystem services, with increased commercial fertilisers, but also local health and nutrition from more restricted diets (e.g., Kuhnlein, Erasmus, and Spigelski 2009). Furthermore, the abandonment of traditional agriculture is contributing significantly to the loss of indigenous nutritional heritage and culture. These issues are seen in Nubia (northern Sudan) where several cereals and pulses that were major food and fodder crops in the middle of the twentieth century have become more minor food crops in recent decades. These include hulled barley (Hordeum vulgare L), sorghum (Sorghum bicolor (L.) Moench) and the pulse crops lablab (Dolichos lablab L.) and Lupinus albus L. (Figure 4). They are more low-input, arid and heat tolerant and 'risk-free' than the newer cash crops which can only be grown in the winter months. These crops also have a long history in the archaeological record further suggesting their suitability to regional environmental conditions (Ryan 2018).

Discussions with farmers showed that changes in crops grown in recent decades are due to a range of factors such as cash crop introductions, the shift from waterwheels to diesel pumps, processing methods and attitudes towards foodstuffs.

Archaeological and anthropological research is already providing perspectives on the benefits of past and alternative crops to increase agricultural resilience and food security. In particular, millet cultivation has been a focus of study in archaeobotany for a number of years (e.g., Beldados et al. 2018; Champion and Fuller 2018; Moreno-Larrazabal et al. 2015; Nasu et al. 2012). There are around 20 species of millet (which are mostly small-seeded grasses largely belonging to the Panicoidea sub-family), including proso millet (Panicum miliaceum L.), 


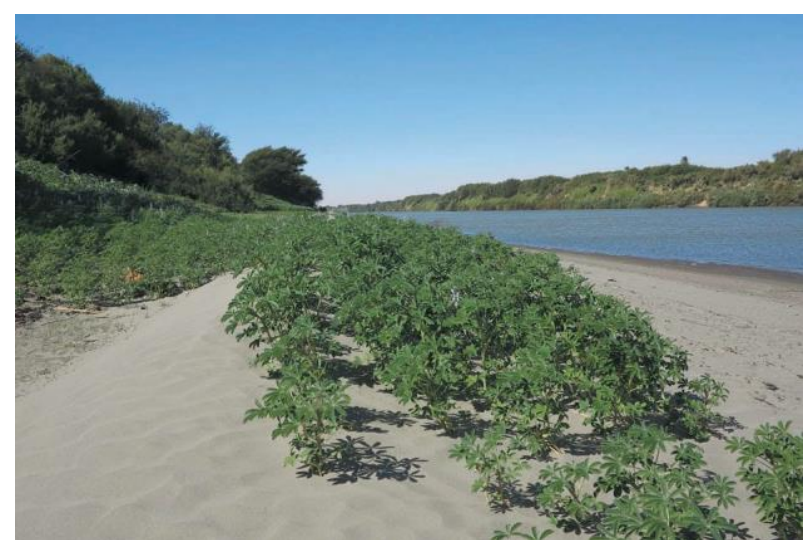

Figure 4. The pulse crop Lupinus albus growing along the edge of Ernetta Island, Sudan. Photo. P. Ryan.

pearl millet (Pennisetum glaucum L.R. Br.), finger millet (Eleusine coracana Gaertn.), kodo millet (Paspalum scrobiculatum L.), foxtail millet (Setaria italica L. Beauv.), little millet (Panicum sumatrense Roth ex Roem. \& Schult.), and barnyard millet (Echinochloa utilis (A.Braun) H.Scholz). They are generally among the most suitable crops for sustaining agriculture and food security on marginal lands with low fertility as they are naturally drought and heat tolerant, grow quickly and have a good nutritional balance (Wang et al. 2018). In areas of Africa and Asia millets have been key crops for thousands of years (e.g. D'Andrea and Casey 2002; Pokharia, Kharakwal, and Srivastava 2014; Zach and Klee 2003); however, present-day agricultural production is based on high water demanding cash crops, which is impacting local hydrology and contributing to significant land use change. Further, climate change models show an impact on soil water balance that will lead to changes in soil evaporation and plant transpiration, shortening the crop growth period and crop yield (Kang, Khan, and Ma 2009). Thus, many believe that the re- instatement of past millet cultivation would be a solution to alleviate ecological degradation, reduce crop risk and increase productivity.

Other crops are also being examined and genetic studies are beginning to show the adapt- ability of species such as buckwheat (Fagopyrum esculentum L. Moench) and barley (Hordeum vulgare L.) to localised conditions, with landraces having varied growing tolerances (e.g. Hunt, Shang, and Jones 2018; Lister et al. 2018; Palmer et al. 2009). Barley, in particular, is not often thought of as an important food crop due to its primary use as animal feed or for malting and brewing, yet it is more arid resistant than wheat. In Ethiopia and many other developing countries, barley - including hulled barley - is used as an important food crop (Shewayrga and Sopade 2011). Even in the recent past, barley has had a more prominent role. For example, in northern Sudan hulled barley was a primary food crop, taking only 90 days to grow, and was typically used to make flatbread until the $1960 \mathrm{~s}$, but today this tradition is all but forgotten in many villages. It has also diminished in importance as a fodder crop (Ryan 2017).

Understanding the genetic basis of environmental adaptation in crops is, therefore, an important element in food security. Genetic erosion occurring with the loss of local species and varieties is dangerously shrinking the genetic pool that is available for natural selection. The study of plant domestication has led to significant insights into the domestication process of certain species and has provided models for the study of plant evolutionary genetics in natural populations (e.g. Allaby, Kitchen, and Fuller 2015; Allaby, Ware, and Kistler 2018; Olsen and Wendel 2013). An example of this is seen from a study by Gross et al. (2014) who examined changes in genetic diversity within apple cultivars (Malus $\times$ domestica) across many centuries. They highlighted that although generally diversity is not under immediate threat in the wider population, those cultivars used in large-scale commercial production have a much lower diversity. This implies that pests and climate change are still a threat to the apple industry, but that these pools of genetic diversity are 
available to improve resilience in the crops (Gross et al. 2014).

Some research programmes are also investigating ancient crops and wild relatives with properties that tolerate adverse environmental conditions and help overcome immunity issues (e.g., Palmgren et al. 2015; Engelhardt, Stam, and Hückelhoven 2018). The Adapting Agriculture to Climate Change: Collecting, Protecting and Preparing Crop Wild Relatives project, managed by the Global Crop Diversity Trust (Crop Trust) within the Royal Botanic Gardens, Kew is in partnership with genebanks and plant breeding programs around the world. Here wild relatives of crops are identified, collected and preserved, in order to store potential traits that could contribute to climate change adaptions in crops for the future (Dempewolf et al. 2014).

\section{Land use change}

Agriculture alters land directly and indirectly by changing soil properties and underlying soil processes, as well as changing geomorphic and hydrologic conditions and ecosystems. It is therefore important to understand landscape and soil change, as the degree of change is usually accelerated by human activities and understanding long-term damage will inform management strategies to conserve soils and their productivity. In addition, relatively short-term studies on modern landscapes and farming practices can provide somewhat simplistic assumptions that cultural continuity, over say 50-100 years, constitutes evidence of sustainable resource use or that its abandonment demonstrates its unsustainability (Stump 2010). Thus, a highly interdisciplinary approach is needed to assess sustainability; requiring details on how the system functioned, the resources available, the environmental context, social interactions, and trade and how they all interact and change through time (e.g., Lang and Stump 2017).

The record of early agriculture, therefore, provides a long-term perspective on land use and humanenvironmental interaction, responses to climate change, anthropogenic soil processes and land use sustainability (e.g., Sandor and Eash 1991; Sandor and Homburg 2017). Terracing and irrigation canals are some of the most visible agricultural management strategies in ancient agricultural landscapes. Although found all around the world, the longer-term history of terracing and irrigation, and its relationship to human populations and food economies are not well understood. One study has recently shown how erosion isn't always negative in the abandoned agricultural landscape at Engaruka, Tanzania (Lang and Stump 2017; Stump and Richer 2017). Here farmers captured vast amounts of alluvial sediments behind thousands of drystone check dams and utilized artificial channels and canals for crop irrigation and sediment transport through the exploitation of the local river and from natural soil erosion. This system maintained soil fertility and avoided salinization over several centuries and is suggested to be evidence of a resilient system within an agriculturally marginal zone (Lang and Stump 2017). A similar sediment capture system is also seen in Konso, Ethiopia (Ferro Vázquez et al. 2017). These archaeological investigations have changed the view that terracing in these regions were designed to conserve soil in situ and suggests that a reassessment of sediment traps is needed to understand their agricultural potential for the future (Lang and Stump 2017; Stump and Richer 2017).

Aquaculture also has a long history, yet few have examined its historical past and so its potential for future sustainability studies is largely untapped (Beveridge and Little 2002). Clay models of irrigated agricultural systems and especially rice-fish farming date back to the later Han Dynasty (25-220 AD) (Halwart and Gupta 2004, 3). In Europe, the Romans are documented as being among the first to build coastal aquaculture ponds (by 2200 B.P.), while monasteries throughout the Middle Ages were important in developing carp culture amongst farmers (Beveridge and Little 2002). Similarly, ancient Hawaiian aquaculture also provides examples of manmade fish enclosures and their decline after European contact (Costa- Pierce 1987). Thus, like agriculture, aquaculture has been shaped by changes in society, politics, technology, and the environment for millennia. More recently traditional aquaculture practices have been abandoned in favour of intensification (Fernando 1993), yet with over 161 million hectares of land being used today for rice cultivation, these flooded conditions provide an opportunity to learn from the past and implement sustainable aquaculture systems. 


\section{Conclusions for future research}

To meet the challenges of feeding the world in a healthy, equitable, sustainable, and resilient way, researchers need to work across disciplines and sectors to share knowledge, exchange ideas and create solutions. The benefits of sustainable agriculture are well known, yet critical environmental, social, economic, and institutional challenge are still to be overcome and a more holistic way of thinking and working is needed to provide an understanding of how problems are connected, their root causes, and where critical leverage points might be. The food systems framework is one such method to help identify and model fundamental proper- ties in the food system and stimulate discussion on options for change and ensure that its essential outcomes are maintained or enhanced over time and across generations. Archaeology and Ethnography, therefore, have an opportunity to join the debate and provide useful data around food security and agricultural development over time and under different challenges. For example, ethnographic and historical studies have the potential to provide information about crop introductions, cultivation methods, land management and other adaptive strategies within local environmental and cultural contexts. Equally, the archaeological record comprises a rich, diverse, and global dataset resulting from the successes and failures of numerous societies and their interactions with the environment. Although the sparse and incomplete nature of this record can make it difficult to inferentially reconstruct past societies in sufficient detail to help guide decision-makers, few have attempted to bridge the gap between the past and present. Much of this may be due to inherent issues in cross-disciplinary research, such as terminological misunderstandings and impenetrable conceptual frameworks, as well as divergences in publication cultures. Our challenge is to, therefore, improve communication and not be trapped within disciplinary silos and specialist terminologies and join the growing discourse on food security for a better future for us all.

\section{Acknowledgments}

We would like to thank everyone that participated in the conference 'Lessons from The Past: Archaeology, Anthropology and The Future of Food', held at the Oxford Martin School, Oxford on 23 August 2018 and organized by Kelly Reed and Philippa Ryan. The conference was supported by the Oxford Martin School programme on the Future of Food, the Global Challenge Research Fund (GCRF) and the Arts and Humanities Research Council (AHRC), as part of the "Nubian traditional knowledge and agricultural resilience, crop choices and endangered cultural heritage project" (P. Ryan grant no. AH/R004536/1) as well as the Association for Environmental Archaeology (AEA). A special thank you to Charles Godfray, John Ingram, Dorian Fuller, Mark Nesbitt, Neal Spencer and Caroline Cartwright for their support and advice.

\section{Funding}

This work was supported by the Arts and Humanities Research Council [AH/R004536/1]. 


\section{Notes on contributors.}

Kelly Reed is the Programme Manager for the Oxford Martin Programme on the Future of Food, which links together existing research on the food system at Oxford and supports new interdisciplinary research that addresses the challenges of feeding the global population sustainably, healthily, and equitably. A substantive part of this work involves project managing the Wellcome Trust funded Livestock, Environment and People (LEAP) Project, which aims to understand the health, environment, social and economic effects of meat and dairy consumption to provide evidence and tools for decision makers to promote healthy and sustainable diets. Kelly is an archaeobotanist with interests in food systems, agricultural development, cultural adaptations to environmental change and global sustainability. Her work focuses predominantly on the reconstruction of past diet and subsistence strategies in the Balkans from the Neolithic to the Late Middle Ages (6000 BC - 16th Century AD). She is particularly interested in exploring how archaeology and anthropology can help inform current food systems issues, especially as they are tools well-suited to investigating food security and agricultural development over different time frames and under different challenges.

Philippa Ryan is a Research Fellow in Economic Botany at the Royal Botanic Gardens, Kew, where her research specialization includes ethnobotany, traditional agriculture, and food. Previously, she worked at the British Museum as an ethnobotanist and archaeobotanist. Between 2013-2016 Philippa was Principal Investigator for the AHRC funded 'Sustainability and subsistence systems in a changing Sudan' project which investigated ancient and recent crop changes; and following this in 2018 of a 'follow-on' AHRC GCRF project Nubian traditional knowledge and agricultural resilience, crop choices and endangered cultural heritage.

\section{Orcid}

Kelly Reed http://orcid.org/0000-0002-7460-8057

Philippa Ryan http://orcid.org/0000-0001-6645-9744 


\section{References}

Allaby, R. G., J. L. Kitchen, and D. Q. Fuller. 2015. "Surprisingly Low Limits of Selection in Plant Domestication."

Evolutionary Bioinformatics Online 11 (Suppl 2): 41-51. doi:10.4137/EBO.S33495.

Allaby, R. G., R. Ware, and L. Kistler. 2018. "A Re-Evaluation of the Domestication Bottleneck from Archaeogenomic Evidence.” Evolutionary Applications OO: 1-9. doi:10.1111/eva.12680.

Arneborg, J., N. Lynnerup, and J. Heinemeier. 2012. "Human Diet and Subsistence Patterns in Norse Greenland Ad C. 980-Ad C. 1450: Archaeological Interpretations.” Journal of the North Atlantic 3: 119-133. doi:10.3721/037.004.s309.

Azadi, H., A. Samiee, H. Mahmoudi, Z. Jouzi, P. Rafiaani Khachak, P. De Maeyer, and F. Witlox. 2016. "Genetically Modified Crops and Small-Scale Farmers: Main Opportunities and Challenges." Critical Reviews in Biotechnology 36 (3): 434-446. doi:10.3109/07388551.2014.990413.

Beldados, A., A. Manzo, C. Murphy, C. J. Stevens, and D. Q. Fuller. 2018. "Evidence of Sorghum Cultivation and Possible Pearl Millet in the Second Millennium BC at Kassala, Eastern Sudan." In Plants and People in the African Past: Themes and Objectives of Archaeobotany, edited by A. Mercuri, A. D‘Andrea, R. Fornaciari, and A. Höhn, 503-528. Switzerland: Springer.

Berkes, F., J. Colding, and C. Folke. 2000. "Rediscovery of Traditional Ecological Knowledge as Adaptive Management.” Ecological Applications 10: 1251-1262. doi:10.1890/1051-

0761(2000)010[1251:ROTEKA]2.0.CO;2. Bernstein, L., P. Bosch, O. Canziani, Z. Chen, R. Christ, O.

Davidson, W. Hare, et al. 2007. Climate Change 2007:Synthesis Report. Cambridge: Cambridge University Press.

Beveridge, M. C., and D. C. Little. 2002. "The History of Aquaculture in Traditional Societies." In Ecological Aquaculture: The Evolution of the Blue Revolution, edited by B. A. Costa-Pierce, 3-29. Oxford: Blackwell Science. Bogaard, A., D. Filipović, A. Fairbairn, L. Green, E. Stroud, D. Fuller, and M. Charles. 2017.

"Agricultural Innovation and Resilience in a Long-Lived Early Farming Community: The 1,500-Year Sequence at Neolithic to Early Chalcolithic Çatalhöyük, Central Anatolia." Anatolian Studies 67: 1-28.

doi:10.1017/S0066154617000072.

Bowman, M., and D. Zilberman. 2013. "Economic Factors Affecting Diversified Farming Systems." Ecology and Society 18 (1). http://www.jstor.org/stable/26269286

Campbell, B. M., P. Thornton, R. Zougmoré, P. Van Asten, and L. Lipper. 2014. "Sustainable Intensification: What Is Its Role in Climate Smart Agriculture?." Current Opinion in Environmental Sustainability 8: 39-43. doi:10.1016/j.cosust.2014.07.002.

Champion, L., and D. Q. Fuller. 2018. "New Evidence on the Development of Millet and Rice Economies in the Niger River Basin: Archaeobotanical Results from Benin." In Plants and People in the African Past: Themes and Objectives of Archaeobotany, edited by A. Mercuri, A. D “Andrea, R. Fornaciari, and A. Höhn, 529-547. Switzerland: Springer.

Cooper, J., and P. Sheets, eds. 2012. Surviving Sudden Environmental Change: Answers from Archaeology. Boulder: University of Colorado Press.

Costa- Pierce, B. 1987. “Aquaculture in Ancient Hawaii.” BioScience 37 (5): 320-331. doi:10.2307/1310688. Costanza, R., L. J. Graumlich, and W. Stefen, Eds. 2007. Sustainability or Collapse? an Integrated History and Future of People on Earth. Cambridge: MIT Press.

D‘Andrea, A. C., and J. Casey. 2002. "Pearl Millet and Kintampo Subsistence." African Archaeological Review 19: 147-173. doi:10.1023/A:1016518919072.

DeMenocal, P. 2001. "Cultural Responses to Climate Change during the Late Holocene.” Science 292 (5517): 667-673. http://www.jstor.org/stable/3083536

Dempewolf, H., R. J. Eastwood, L. Guarino, C. K. Khoury, J. V. Müller, and J. Toll. 2014. “Adapting Agriculture to Climate Change: A Global Initiative to Collect, Conserve, and Use Crop Wild Relatives." Agroecology and Sustainable Food Systems 38 (4): 369-377. doi:10.1080/21683565.2013.870629.

Dugmore, A. J., T. H. McGovern, O. Vésteinsson, J. Arneborg, R. Streeter, and C. Keller. 2012. "Cultural Adaptation, Compounding Vulnerabilities Conjunctures in Norse Greenland." Proceedings of the National Academy of Sciences of the United States of America 109 (10): 3658-3663. doi:10.1073/pnas.1115292109. 
Ellis, E. C., J. O. Kaplan, D. QFuller, S. Vavrus, K. K. Goldewijk, and P. H. Verburg. 2013. "Used Planet: A Global History." Proceedings of the National Academy of Sciences 110 (20): 7978-7985.

doi:10.1073/pnas.1217241110. Engelhardt, S., R. Stam, and R. R. Hückelhoven. 2018. “Good Riddance? Breaking Disease Susceptibility in the

Era of New Breeding Technologies.” Agronomy 8 (7): 114. doi:10.3390/agronomy8070114.

Ericksen, P. J. 2008. “Conceptualizing Food Systems for Global Environmental Change Research.” Global Environmental Change 18: 234-245. doi:10.1016/j.gloenvcha.2007.09.002.

FAO. 1996. "The Rome Declaration on World Food Security and the World Food Summit Plan of Action." Accessed 27 March 2017. http://www.fao.org/docrep/003//w3613e/w3613e00.htm

FAO. 2004. "Building on Gender, Agrobiodiversity and Local Knowledge.” Accessed 20 September 2018. http://www.fao.org/docrep/007/y5609e/y5609e02.htm

FAO. 2017a. Nutrition-Sensitive Agriculture and Food Systems in Practice. Rome: FAO.

http://knowledge4food. net/knowledge-portal-item/nutrition-sensitive-agriculture-food-systems-practice/

FAO. 2017b. “The Future of Food and Agriculture.” website. Accessed 21 September 2018. http://www.fao. org/3/a-i6583e.pdf

Fernando, C. H. 1993. "Rice Field Ecology and Fish Culture - An Overview.” Hydrobiologia 259: 91-113. doi:10.1007/BF00008375.

Ferro Vázquez, C., C. Lang, J. Kaal, and D. Stump. 2017. "When Is a Terrace Not a Terrace? the Importance of Understanding Landscape Evolution in Studies of Terraced Agriculture.” Journal of Environmental Management 202 (Pt 3): 500-513. doi:10.1016/j.jenvman.2017.01.036.

Fisher, M. C., D. A. Henk, C. J. Briggs, J. S. Brownstein, L. C. Madoff, S. L. McCraw, and S. J. Gurr. 2012. "Emerging Fungal Threats to Animal, Plant and Ecosystem Health.” Nature 484: 186-194. doi:10.1038/ nature10947.

Flohr, P., D. Fleitmann, R. Matthews, W. Matthews, and S. Black. 2016. "Evidence of Resilience to past Climate Change in Southwest Asia: Early Farming Communities and the 9.2 And 8.2 Ka Events." Quaternary Science Reviews 136: 23-39. doi:10.1016/j.quascirev.2015.06.022.

Fuller, D. Q., J. van Etten, J. V. K. Manning, E. Kingwell-Banham, A. Weisskopf, L. Qin, Y. I. Sato, and R. Hijmans. 2011. "The Contribution of Rice Agriculture and Livestock to Prehistoric Methane Levels: An Archaeological Assessment.” Holocene 21: 743-759. doi:10.1177/0959683611398052.

Fumagalli, M., I. Moltke, N. Grarup, F. Racimo, P. Bjerregaard, M. E. Jørgensen, T. S. Korneliussen et al. 2015. "Greenlandic Inuit Show Genetic Signatures of Diet and Climate Adaptation". Science 349: 1343-1347. doi:10.1126/science.aab2319.

Godfray, H. C. J., J. R. Beddington, I. R. Crute, L. Haddad, D. Lawrence, J. F. Muir, J. Pretty, S. Robinson, S. M. Thomas, and C. Toulmin. 2010. "Food Security: The Challenge of Feeding 9 Billion People." Science 327: 812-818. doi:10.1126/science.1185383.

Godfray, H. C. J., and T. Garnett. 2014. "Food Security and Sustainable Intensification.” Philosophical Transactions of the Royal Society (B: Biological Sciences) 369: 20120273. doi:10.1098/rstb.2012.0273.

Graid. 2016. "Development in the Anthropocene: The Role of Resilience. Guidance for Resilience in the Anthropocene: Investments for Development (GRAID) Programme Funded by the Swedish International Development Cooperation Agency (Sida)." https:/graid.earth/briefs/

Graid. 2018. "Ecosystems Matter for Development in the Anthropocene, Stockholm Resilience Centre May 2018." Brief. https://graid.earth/briefs/

Grattan, J., and R. Torrence. 2007. "Beyond Gloom and Doom: The Long-Term Consequences of Volcanic Disasters." In Under the Shadow: The Cultural Impacts of Volcanic Eruptions, edited by J. Grattan and R. Torrence, 1-18. Walnut Creek, California: Left Coast Press.

Gross, B. L., A. D. Henk, C. M. Richards, G. Fazio, and G. M. Volk. 2014. “Genetic Diversity in Malus X Domestica (Rosaceae) through Time in Response to Domestication.” American Journal of Botany 101 (10): 1770-1779. doi:10.3732/ajb.1400297. PubMed PMID: WOS:000344010400017. pmid:25326619.

Halstead, P., and J. O’Shea. 1989. “Cultural Response to Risk and Uncertainty.” In Bad Year Economics, edited by P. Halstead and J. O’Shea, 1-7. Cambridge: Cambridge University Press. 
Halwart, M., and M. V. Gupta. 2004. Culture of Fish in Rice Fields. Rome: FAO.

Hunt, H. V., X. Shang, and M. K. Jones. 2018. "Buckwheat: A Crop from outside the Major Chinese

Domestication Centres? A Review of the Archaeobotanical, Palynological and Genetic Evidence." Vegetation History and Archaeobotany 27: 493. doi:10.1007/s00334-017-0649-4.

Ingram, J., P. Ericksen, and D. Liverman, eds. 2010. Food Security and Global Environmental Change. London: Earthscan.

Ingram, J. S. I. 2011. “A Food Systems Approach to Researching Food Security and Its Interactions with Global Environmental Change.” Food Security 3: 417-431. doi:10.1007/s12571-011-0149-9.

Jackson, R., A. Dugmore, and F. Riede. 2017. "Towards a New Social Contract for Archaeology and Climate Change Adaptation.” Archaeological Review from Cambridge 32 (2): 197-221.

Jacobsen, S. E. 2011. "The Situation for Quinoa and Its Produc-Tion in Southern Bolivia: From Economic Success to Environ-Mental Disaster.” Journal of Agronomy and Crop Science 197: 390-399. doi:10.1111/ j.1439-037X.2011.00475.X.

Kang, Y., S. Khan, and X. Ma. 2009. "Climate Change Impacts on Crop Yield, Crop Water Productivity and Food Security - A Review.” Progress in Natural Science 19 (12): 1665-1674. doi:10.1016/j.pnsc.2009.08.001.

Kerner, S., R. Dann, and P. Bangsgaad, eds.. 2015. Climate and Ancient Societies. Copenhagen: Museum Tusculanum Press: University of Copenhagen.

Kintisch, E. 2016. “Why Did Greenland'S Vikings Disappear?.” Science 354: 696-701. doi:10.1126/science. aal1794.

Kirch, P. V. 2005. “Archaeology and Global Change: The Holocene Record.” Annual Review of Environment and Resources 30 (1): 409-440. doi:10.1146/annurev.energy.29.102403.140700.

Kuhnlein, H. V., B. Erasmus, and D. Spigelski. 2009. Indigenous Peoples' Food Systems: The Many Dimensions of Culture, Diversity and Environment for Nutrition and Health. Rome: FAO and Centre for Indigenous Peoples' Nutrition and Environment.

Lang, C., and D. Stump. 2017. "Geoarchaeological Evidence for the Construction, Irrigation, Cultivation, and Resilience of 15th-18th Century AD Terraced Landscape at Engaruka, Tanzania." Quaternary Research 88 (3): 382-399. doi:10.1017/qua.2017.54.

Laparidou, S., and A. M. Rosen. 2015. "Intensification of Production in Medieval Islamic Jordan and Its Ecological Impact: Towns of the Anthropocene.” The Holocene 25 (10): 1685-1697. doi:10.1177/ 0959683615594470.

Lemaire, G., A. Franzluebbers, P. C. D. F. Carvalho, and B. Dedieu. 2014. "Integrated Crop-Livestock Systems: Strategies to Achieve Synergy between Agricultural Production and Environmental Quality." Agriculture, Ecosystems \& Environment 190 (2): 4-8. doi:10.1016/j.agee.2013.08.009.

Lin, B. B. 2011. "Resilience in Agriculture through Crop Diversification: Adaptive Management for Environmental Change.” BioScience 61 (3): 183-193. doi:10.1525/bio.2011.61.3.4.

Lister, D. L., H. Jones, H. R. Oliveira, C. A. Petrie, X. Liu, J. Cockram, C. J. Kneale, O. Kovaleva, and M. K. Jones. 2018. "Barley Heads East: Genetic Analyses Reveal Routes of Spread through Diverse Eurasian Landscapes.” PLOS ONE 13 (7): e0196652. doi:10.1371/journal.pone.0196652.

Marston, J. M. 2017. Agricultural Sustainability and Environmental Change at Ancient Gordion (Gordion Special Studies 8). Philadelphia: University of Pennsylvania Press.

Marston, J.M. 2015. “Modeling Resilience and Sustainability in Ancient Agricultural Systems.” Journal of Ethnobiology 35 (3): 585-605.

Massawe, F., S. Mayes, and A. Cheng. 2016. "Crop Diversity: An Unexploited Treasure Trove for Food Security."

Trends in Plant Science 21: 365-368. doi: 10.1016/j.tplants.2016.02.006.

McGovern, T. H., G. F. Bigelow, T. Amorosi, and D. Russell. 1988. "Northern Islands, Human Error, and Environmental Degradation: A View of Social and Ecological Change in the Medieval North Atlantic." Human Ecology 16 (3): 225-270. doi:10.1007/BF00888447.

Moreno-Larrazabal, A., A. Teira-Brión, I. Sopelana-Salcedo, A. Arranz-Otaegui, and L. Zapata. 2015. 
"Ethnobotany of Millet Cultivation in the North of the Iberian Peninsula." Vegetation History and Archaeobotany 24 (4): 541-554. doi:10.1007/s00334-015-0518-y.

Nasu, H., H. B. Gu, A. Momohara, and Y. Yasuda. 2012. "Land-Use Change for Rice and Foxtail Millet Cultivation in the Chengtoushan Site, Central China, Reconstructed from Weed Seed Assemblages." Archaeological and Anthropological Sciences 4 (1): 1-14. doi:10.1007/s12520-011-0077-9.

Nunn, P., and R. Kumar. 2018. "Understanding Climate-Human Interactions in Small Island Developing States (SIDS): Implications for Future Livelihood Sustainability.” International Journal of Climate Change Strategies and Management 10 (2): 245-271. doi:10.1108/IJCCSM-01-2017-0012.

Olsen, K. M., and J. F. Wendel. 2013. “Crop Plants as Models for Understanding Plant Adaptation and Diversification.” Frontiers in Plant Science 4: 290. doi:10.3389/fpls.2013.00290.

Palmer, S. A., J. D. Moore, A. J. Clapham, P. Rose, and R. G. Allaby. 2009. “Archaeogenetic Evidence of Ancient Nubian Barley Evolution from Six to Two-Row Indicates Local Adaptation.” PLoS One 4: e6301. doi:10.1371/ journal.pone.0006301.

Palmgren, M. G., A. K. Edenbrandt, S. E. Vedel, M. M. Andersen, X. Landes, J. T. Østerberg, J. Falhof, et al. 2015. “Are We Ready for Back-To-Nature Crop Breeding?.” Trends in Plant Science 20: 155-164. doi:10.1016/j. tplants.2014.11.003.

Pingali, P. L. 2012. “Green Revolution: Impacts, Limits, and the Path Ahead.” Pnas 109: 12302-12308. doi:10.1073/pnas.0912953109.

Pokharia, A. K., J. S. Kharakwal, and A. Srivastava. 2014. "Archaeobotanical Evidence of Millets in the Indian Subcontinent with Some Observations on Their Role in the Indus Civilization." Journal of Archaeological Science 42: 442-455. doi:10.1016/j.jas.2013.11.029.

Redman, C. L. 1999. Human Impact on Ancient Environments. Tucson: University of Arizona Press. Redman, C.L. 2005. "Resilience Theory in Archaeology." American Anthropologist 107: 70-77.

Reed, K., R. Collier, R. White, R. Wells, J. Ingram, R. Borelli, B. Haesler et al. 2017. “Training Future Actors in the Food System: A New Collaborative Cross-Institutional, Interdisciplinary Training Programme for Students.” Exchanges: the Warwick Research Journal 4 (2): 201-218.

Rippon, S. 2000. The Transformation of Coastal Wetlands. Exploitation and Management of Marshland Landscapes in North-West Europe during the Roman and Medieval Periods. Oxford: Oxford University Press. Rockman, M. 2011. "The Necessary Roles of Archaeology in Climate Change Mitigation and Adaptation." In Archaeology in Society: Its Relevance in the Modern World, edited by M. Rockman and J. Flatman, 193-215. New York: Springer.

Rosen, A. M. 2007. Civilizing Climate: Social Responses to Climate Change in the Ancient near East: The Social Impact of Climate Change in the Ancient near East. Lanham: Altamira Press.

Rosenzweig, C., A. Iglesias, X. B. Yang, P. R. Epstein, and E. Chivian. 2001. "Climate Change and Extreme Weather Events; Implications for Food Production, Plant Diseases, and Pests." Global Change \& Human Health 2: 90-104. doi:10.1023/A:1015086831467.

Ruddiman, W. F., D. Q. Fuller, J. E. Kutzbach, P. C. Tzedakis, J. O. Kaplan, E. C. Ellis, S. J. Vavrus, et al. 2016. "Late Holocene Climate: Natural or Anthropogenic?” Reviews of Geophysics 54: 93-118. doi:10.1002/2015RG000503.

Ryan, P., and A. Rosen. 2016. "Managing Risk through Diversification in Plant Exploitation during the 7th Millennium BC: The Microbotanical (Phytolith) Record at Çatalhöyük.” In Climate and Cultural Change in Prehistoric Europe and the near East, edited by P. F. Biehl and O. Nieuwenhuyse, Volume 3 of the Distinguished Monograph Series of the Institute for European and Mediterranean Archaeology, 117-133. New York: Suny Press.

Ryan, P. 2017. "From Raw Resources to Food Processing; Archaeobotanical, Archaeological, and Ethnographic Insights from New Kingdom Amara West and Present-Day Ernetta Island in Northern Sudan.” In Exploring the Materiality of Food "Stuffs": Archaeological and Anthropological Perspectives, edited by L. Steel and K. Zinn, 15-38. Oxford: Routledge.

Ryan, P. 2018. Nubia past and Present; Agriculture Crops and Food. London and Khartoum: British Museum.

Ryan, P., and K. Homewood. 2016. "Sustainability and Subsistence Systems in a Changing Sudan: Ethnobotanical and Archaeobotanical Investigations into Past, Present and Future Crop Choices.” Project 
Report, for the Sustainability and subsistence systems in a changing Sudan project.

Sandor, J. A., and J. A. Homburg. 2017. “Anthropogenic Soil Change in Ancient and Traditional Agricultural Fields in Arid to Semiarid Regions of the Americas." Journal of Ethnobiology 37 (2): 196-217. doi:10.2993/ 0278-0771-37.2.196.

Sandor, J. A., and N. S. Eash. 1991. "Significance of Ancient Agricultural Soils for Long-Term Agronomic Studies and Sustainable Agriculture Research.” Agronomy Journal 83: 29-37.

Scarborough, V. L. 2010. "The Archaeology of Sustainability: Mesoamerica.” Ancient Mesoamerica 20 (2): 197-203. Shelef, O., P. J. Weisberg, and F. D. Provenza. 2017. "The Value of Native Plants and Local Production in an Era of Global Agriculture." Frontiers in Plant Science 8: 2069. doi:10.3389/fpls.2017.02069.

Shewayrga, H., and P. A. Sopade. 2011. "Ethnobotany, Diverse Food Uses, Claimed Health Benefits and Implications on Conservation of Barley Landraces in North Eastern Ethiopia Highlands." Journal of Ethnobiology and Ethnomedicine 7 (1): 1-15. doi:10.1186/1746-4269-7-19.

Skarbø, K. 2015. "From Lost Crop to Lucrative Commodity: Conservation Implications of the Quinoa Renaissance.” Human Organization 74 (1): 86-99. doi:10.17730/humo.74.1.09276v70638x8q01.

Soens, T. 2013. "Flood Security in the Medieval and Early Modern North Sea Area: A Question of Entitlement?"

Environment and History 19 (2): 209-232. doi:10.3197/096734013X13642082568651.

Springmann, M., M. Clark, D. Mason-D’Croz, K. Wiebe, B. L. Bodirsky, L. Lassaletta, W. de Vries, et al. 2018. "Options for Keeping the Food System within Environmental Limits." Nature 562: 519-525. Accessed 10 Oct 2018. doi: 10.1038/s41586-018-0594-0.

Star, B., J. H. Barrett, A. T. Gondek, and S. Boessenkool. 2018. "Ancient DNA Reveals the Chronology of Walrus Ivory Trade from Norse Greenland.” Proceedings of the Royal Society B 285 (1884): 20180978. doi:10.1098/ rspb.2018.0978.

Strange, R. N., and P. R. Scott. 2005. "Plant Disease: A Threat to Global Food Security." Annual Review of Phytopathology 43: 83-116. doi:10.1146/annurev.phyto.43.113004.133839.

Stump, D. 2010. "Ancient and Backward or Long-Lived and Sustainable: The Role of the past in Debates Concerning Rural Livelihoods and Resource Conservation in Eastern Africa." World Development 38 (9): 1251-1262. doi:10.1016/j.worlddev.2010.02.007.

Stump, D., and S. Richer. 2017. Terraces are Good, but Sediment Traps are Better. AAREA Policy Brief No 1. University of York.

Termeer, J. A. M. C., S. Drimie, J. Ingram, L. Pereirad, and M. J. Whittingham. 2018. “A Diagnostic Framework for Food System Governance Arrangements: The Case of South Africa." NJAS - Wageningen Journal of Life Sciences 84: 85-93. doi:10.1016/j.njas.2017.08.001.

Tilman, D., C. Balzer, J. Hill, and B. L. Befort. 2011. "Global Food Demand and the Sustainable Intensification of Agriculture.” Proceedings of the National Academy of Sciences 108 (50): 20260-20264. doi:10.1073/ pnas. 1116437108.

Turner, B. L., II, and J. Sabloff. 2012. "Classic Period Collapse of the Central Maya Lowlands: Insights about Human-Environment Relationships for Sustainability." Proceedings of the National Academy of Sciences 109 (35): 13908-13914. doi:10.1073/pnas.1210106109.

Van de Noort, R. 2011a. “Conceptualising Climate Change Archaeology.” Antiquity 85 (329): 1039-1048. doi:10.1017/S0003598X00068472.

Van de Noort, R. 2011b. North Sea Archaeologies; a Maritime Biography 10000 BC - AD 1500. Oxford: Oxford University Press.

van der Leeuw, S. F. 2008. “A New Initiative on Vulnerability, Resilience and Adaptation.” IHDP Update 1 Arizona State University and Santa Fe Institute https://www.unisdr.org/preventionweb/files/7919_ IHDPUpdate1.pdf

Wang, J., S. K. Vanga, R. Saxena, V. Orsat, and V. Raghavan. 2018. "Effect of Climate Change on the Yield of Cereal Crops: A Review.” Climate 6 (2): 41. doi:10.3390/cli6020041.

Zach, B., and M. Klee. 2003. "Four Thousand Years of Plant Exploitation in the Chad Basin of NE Nigeria II: 
Discussion on the Morphology of Caryopses of Domesticated Pennisetum and Complete Catalogue of the Fruits and Seeds of Kursakata." Vegetation History and Archaeobotany 12: 187-204. doi:10.1007/s00334-003-0016-5. 